KeRRIDGe, D. (1958). J. gen. Microbiol. 19, 497-506

\title{
The Effect of Actidione and other Antifungal Agents on Nucleic Acid and Protein Synthesis in Saccharomyces carlsbergensis
}

\author{
BY D. KERRIDGE \\ Department of Biochemistry, University of Cambridge
}

SUMMARY: The antifungal compound actidione has been found to inhibit both nucleic acid and protein synthesis in Saccharomyces carlsbergensis. At the minimum growth inhibitory concentration synthesis of deoxyribonucleic acid and protein is completely inhibited, whereas the synthesis of ribonucleic acid continues for some time after the addition of the antibiotic to the culture. Some other antifungal agents were found to inhibit both nucleic acid and protein synthesis, but in no case was any differential effect obtained.

Investigations on the mode of action of many antibiotics have shown that in a number of cases the biochemical lesion resulting in the bacteriostatic or bacteriocidal effect is located in the sequence of reactions leading to the synthesis of nucleic acid or protein. Fitzgerald, Bernheim \& Fitzgerald (1948) reported the inhibition by streptomycin of the synthesis of the enzyme system involved in the adaptive utilization of benzoic acid by Mycobacterium lacticola. Gale \& Paine (1951) and Gale \& Folkes (1953) found that at the minimum growth inhibitory concentration, chloramphenicol, aureomycin and terramycin had little or no effect on respiration, fermentation, or the accumulation of glutamic acid by Staphylococcus aureus, but completely inhibited the synthesis of protein by washed suspensions of this organism. In the presence of concentrations of these antibiotics which completely inhibit protein synthesis, there is an increased rate of nucleic acid synthesis. Chloramphenicol has a similar action on nucleic acid and protein synthesis in Escherichia coli (Hahn \& Wisseman, 1951; Wisseman, Hahn, Hopps \& Smadel, 1953; Gros \& Gros, 1956). Since the use of antibiotics has provided a useful tool in investigations of the synthesis of nucleic acid and protein in bacteria, a study of the effect of actidione on synthetic processes in the yeast Saccharomyces carlsbergensis was initiated. Actidione is produced by Streptomyces griseus (Whiffen, Bohonas \& Emerson, 1946) has a high degree of activity against many yeasts and fungi (Whiffen, 1948), but has little or no effect on the growth of bacteria or viruses (Hall, Kavanagh \& Asheshov, 1951). Actidione was found by Loveless, Spoerl $\&$ Weisman (1954) to inhibit both growth and cell multiplication of Saccharomyces cerevisiae, but Szilvinyi, Klaus-Hofer \& Rauch (1954) were unable to demonstrate any relationship between actidione sensitivity and other physiological properties in Saccharomyces carlsbergensis. Although the growth of Staphylococcus aureus is insensitive to actidione Creaser (1955) found that a concentration of $3 \mathrm{mg} . / \mathrm{ml}$. inhibited by $72 \%$ the synthesis of the inducible enzyme $\beta$-galactosidase by washed suspensions of this organism. 
The present paper describes the effect of actidione on the synthesis of nucleic acid and protein by Saccharomyces carlsbergensis. Other antifungal agents were also studied for their effect on nucleic acid and protein synthesis in an attempt to elucidate further the inter-relationship between nucleic acid and protein synthesis. A preliminary report of this work has been given (Kerridge, 1957).

\section{METHODS}

Organism and growth medium. The organism used for this study was Saccharomyces carlsbergensis, obtained from the Carlsberg laboratory. It has also been called Saccharomyces mandshuricus. The organism was maintained by weekly subculture in $2 \%(\mathrm{w} / \mathrm{v})$ glucose yeast-extract medium (Davies, Falkiner, Wilkinson \& Peel, 1951). The organism was grown without shaking in the chemically-defined growth medium of Davies (1956) dispensed in $150 \mathrm{ml}$. quantities in Roux bottles. The organism was harvested after $16 \mathrm{hr}$. growth at $30^{\circ}$, washed twice with distilled water and finally resuspended in distilled water to the required concentration. The dry weights of the suspensions were estimated by using a Hilger 'Spekker' absorptiometer previously calibrated for this organism.

Growth inhibition tests. The presence or absence of visible growth was recorded after $16 \mathrm{hr}$. incubation at $30^{\circ}$ using an inoculum of $10^{7}$ organisms/ $10 \mathrm{ml}$. of defined medium (Davies, 1956) containing the growth inhibitory agent under test.

Nucleic acid and protein synthesis. For studies on the synthesis of nucleic acid and protein, Saccharomyces carlsbergensis was resuspended in the defined medium at a concentration equivalent to $1 \mathrm{mg}$. dry weight $/ \mathrm{ml}$. and aerated at $25^{\circ}$. The antibiotics were added at suitable concentrations to the defined medium. After incubation the organisms were harvested by centrifugation. When logarithmically growing organisms were required, the initial suspension density was adjusted to be equivalent to $0.1 \mathrm{mg}$. dry weight $/ \mathrm{ml}$., the growth followed turbidimetrically and the inhibitor added when the culture had reached a suitable suspension density (c. equiv. $0.3 \mathrm{mg}$. dry weight $/ \mathrm{ml}$.). When the incorporation of a ${ }^{14} \mathrm{C}$-labelled amino acid was to be used as a measure of the synthesis of nucleic acid and protein $\left(1-{ }^{14} \mathrm{C}\right)$-glycine $(0 \cdot 1 \mu \mathrm{c} . / \mu$ mole $)$ was added to the incubation medium at a final concentration of $0.1 \mu \mathrm{mole} / \mathrm{ml}$.

At the end of the incubation period, samples containing $c$. equiv. $2 \mathrm{mg}$. dry weight organisms were centrifuged, the organisms washed twice with distilled water and finally resuspended in $5 \%(\mathrm{w} / \mathrm{v})$ trichloroacetic acid (TCA) and stored at $4^{\circ}$ for $2 \mathrm{hr}$. The precipitate was then centrifuged and washed twice with $5 \%(\mathrm{w} / \mathrm{v}) \mathrm{TCA}$. In experiments where the incorporation of ${ }^{14} \mathrm{C}$ labelled glycine was used as a measure of synthesis, the nucleic acid was extracted with $5 \%(\mathrm{w} / \mathrm{v}) \mathrm{TCA}$ at $90^{\circ}$; three $10 \mathrm{~min}$. extractions with $1.0 \mathrm{ml}$. quantities of the TCA solution being sufficient to remove all the nucleic acid (Gale \& Folkes, 1953). The combined supernatant fluids were extracted three times with an equal volume of ether to remove the TCA. The resulting aqueous solution was made up to a known volume with distilled water and a measured sample 
transferred to a $2 \mathrm{~cm} .{ }^{2}$ polythene planchette. A piece of lens tissue and $0.03 \mathrm{ml}$. of $0.1 \%(\mathrm{w} / \mathrm{v})$ aqueous cetyl trimethylammonium bromide were placed on the planchette to facilitate the spreading of the sample. The planchette contents were dried in vacuo and their radioactivity determined by using a Panax Type 100c decadic counter in association with a mica end-window Geiger-Muller tube. Counting was continued for $20 \mathrm{~min}$. or until 1000 counts had been recorded.

The synthesis of nucleic acid was also followed by using the extinction of a hot perchloric acid extract as a measure of the total nucleic acid. The nucleic acid was removed by two 20 min. extractions at $70^{\circ}$ with $2.0 \mathrm{ml}$. $0.5 \mathrm{~N}$-perchloric acid (Ogur \& Rosen, 1950). The deoxyribonucleic acid (DNA), content of the perchloric acid extract was measured by the diphenylamine method of Burton (1956).

For the separation of the nucleic acid into the component ribonucleic acid (RNA) and DNA fractions a modification of the Schmidt \& Thannhauser (1945) procedure was used. The material precipitated with cold TCA from a sample containing $c$. equiv. $6 \mathrm{mg}$. dry-weight organisms was resuspended in $1.0 \mathrm{ml} . \mathrm{N}-\mathrm{NaOH}$ and incubated for $16 \mathrm{hr}$. at $37^{\circ}$. The alkali was neutralized with $1.0 \mathrm{ml}$. $\mathrm{N}-\mathrm{HCl}$ and TCA added to a final concentration of $5 \%(\mathrm{w} / \mathrm{v})$. After leaving for $2 \mathrm{hr}$. at $4^{\circ}$ the precipitate was centrifuged down and washed once with $5 \%(w / v)$ TCA. The combined supernatant fluids constituted the RNA fraction. The DNA was extracted from the residue with $5 \%(w / v)$ TCA at $90^{\circ}$. Both RNA and DNA were estimated spectrophotometrically by measuring the extinction of the extract at $260 \mathrm{~m} \mu$ with a Beckman Model DU spectrophotometer.

The residue after the extraction of the nucleic acid was taken as the protein fraction and was determined: $(a)$ by estimating the nitrogen content by Kjeldahl digestion under the conditions described by Chibnall, Rees \& Williams (1943), the ammonia being collected after distillation in a Markham apparatus (Markham, 1942) and determined colorimetrically with Nesslers reagent as described by Johnson (1941); (b) by measuring the incorporation of ${ }^{14} \mathrm{C}$ labelled glycine into this fraction.

Induction of maltozymase activity in washed suspensions of Saccharomyces carlsbergensis. Induction was carried out aerobically in a system consisting of $(\%, w / v):\left(\mathrm{NH}_{4}\right)_{2} \mathrm{HPO}_{4}, 0 \cdot 1 ;\left(\mathrm{NH}_{4}\right) \mathrm{H}_{2} \mathrm{PO}_{4}, 0 \cdot 1 ;$ maltose, 1.0 ; dissolved in McIlvaine buffer $\mathrm{pH} 5.0$ (equivalent to a final concentration 0.05 M-phosphate; McIlvaine, 1921); S. carlsbergensis at a final suspension density equiv. 1.0 mg. dry weight $/ \mathrm{ml}$.

Estimation of maltozymase activity. The organisms were harvested from the incubation medium by centrifugation, washed twice with distilled water and finally suspended in distilled water to a final concentration equiv. $3.0 \mathrm{mg}$. dry weight $/ \mathrm{ml}$. The maltozymase activity was determined manometrically at $25^{\circ}$, the manometer cups containing $1.5 \mathrm{ml}$. McIlvaine buffer (pH 5.0) and $1.0 \mathrm{ml}$. yeast suspension in the main cup, and $0.5 \mathrm{ml} .5 \%(\mathrm{w} / \mathrm{v})$ maltose in the side arm; the gas phase was nitrogen.

Chemicals. Kerfoots Biochemical Reagent sugars were used throughout; 
other chemicals were of analytical quality. $\left(1^{14} \mathrm{C}\right)$-glycine was obtained from the Radiochemical Centre, Amersham. Actidione was obtained from the Upjohn Company, Kalamazoo, Michigan, U.S.A.

\section{RESULTS}

\section{Effect of actidione on nucleic acid and protein synthesis}

Preliminary investigations. The manometric techniques of Umbreit, Burris \& Stauffer (1949) were used to study the effect of actidione on oxygen consumption and anaerobic production of carbon dioxide by Saccharomyces carlsbergensis in the presence of glucose. Actidione at concentrations up to $1 \mathrm{mg} . / \mathrm{ml}$. inhibited oxygen uptake or carbon dioxide production by not more than $20 \%$. The uptake of glycine and glutamic acid in the presence of glucose into the soluble fraction extractable with cold $5 \%$ (w/v) TCA was not inhibited by actidione at a concentration of $0.1 \mathrm{mg} . / \mathrm{ml}$. DeMoss \& Novelli (1955) demonstrated a soluble protein fraction in micro-organisms which catalyses an L-amino acid dependent exchange of pyrophosphate with ATP; in the presence of excess hydroxylamine the exchange is inhibited and there is a concomitant production of hydroxamic acids. This system was found in S. carlsbergensis and actidione at $0.1 \mathrm{mg} . / \mathrm{ml}$. had no effect on the production of amino acid hydroxamates when the soluble protein fraction obtained from organisms disrupted in the Hughes's press (Hughes, 1951) was incubated with a complete mixture of amino acids $(0.2 \mathrm{mg}$. of each $/ \mathrm{ml}$.) in the presence of $0.6 \mathrm{M}$ hydroxylamine.

Nucleic acid synthesis. Preliminary studies showed that the addition of ${ }^{14} \mathrm{C}$ labelled glycine to a culture of Saccharomyces carlsbergensis resulted in the irreversible incorporation of ${ }^{14} \mathrm{C}$ in the adenine and guanine of the nucleic acid and that this incorporation could be used as a measure of synthesis of nucleic acid. Figure 1 shows the effect of increasing concentrations of actidione on the incorporation of ${ }^{14} \mathrm{C}$-labelled glycine into the nucleic acid fraction of $S$. carlsbergensis during a $2 \mathrm{hr}$. incubation period. Although actidione at the minimum growth inhibitory concentration (0.5-1.0 $\mu \mathrm{g} . / \mathrm{ml}$.) partially inhibited nucleic acid synthesis the inhibition was not complete at concentrations greatly exceeding this. Fractionation of the nucleic acid into RNA and DNA by the method of Schmidt \& Thannhauser showed a differential inhibition of incorporation of glycine carbon into the two types of nucleic acid. Over a $2 \mathrm{hr}$. incubation period with concentrations of actidione greater than $5.0 \mu \mathrm{g} . / \mathrm{ml}$. there was complete inhibition of DNA synthesis whereas the synthesis of RNA was not completely inhibited at $100 \mu \mathrm{g}$. actidione/ml. (Fig. 2). The residual RNA synthesis in the presence of actidione could account for the degree of inhibition observed when total nucleic acid synthesis was measured, since the RNA:DNA ratio in this yeast is of the order of $20: 1$.

The above results were obtained by measuring changes occurring after a $2 \mathrm{hr}$. incubation period and give little indication of any early effects of actidione on nucleic acid synthesis. The rate of incorporation of ${ }^{14} \mathrm{C}$-labelled glycine into the nucleic acid fraction was therefore examined both in washed suspensions 
prepared from $16 \mathrm{hr}$. cultures and in logarithmically growing cultures of Saccharomyces carlsbergensis. In both cases the tracer amino acid and the inhibitor were added simultaneously to the suspension of yeast. Logarithmically growing organisms appeared to be slightly more sensitive to inhibition by actidione, but otherwise the results were similar (Fig. 3), with low concentrations there was little effect on the initial rate of uptake into the nucleic acid

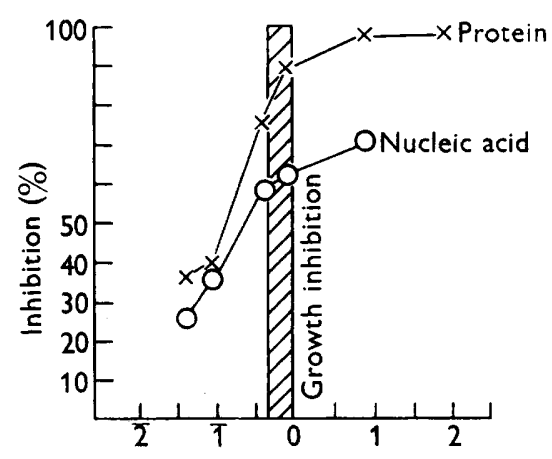

Log concentration actidione $(\mu \mathrm{g} . / \mathrm{ml}$.)

Fig. 1

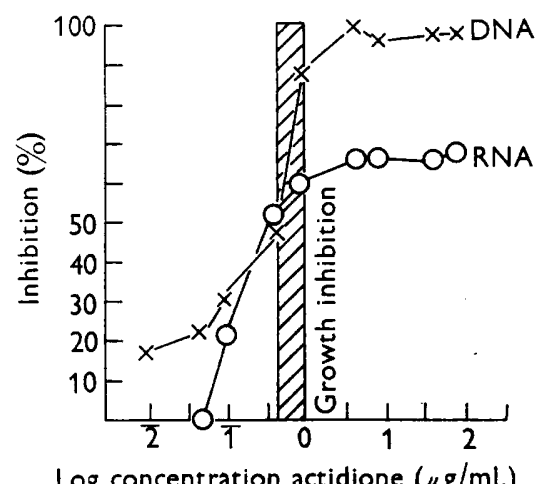

Log concentration actidione $(\mu \mathrm{g} / \mathrm{ml}$.)

Fig. 2

Fig. 1. Inhibition of nucleic acid and protein synthesis by actidione. Saccharomyces carlsbergensis (equiv. $1 \mathrm{mg}$. dry weight $/ \mathrm{ml}$.) was incubated aerobically at $25^{\circ}$ in defined medium containing ${ }^{14} \mathrm{C}$-glycine $(0 \cdot 1 \mu \mathrm{mole} / \mathrm{ml}, 0 \cdot 1 \mu \mathrm{c} / \mu \mathrm{mole})$ and actidione as required. Organisms were harvested after $2 \mathrm{hr}$., fractionated by the Schneider technique and uptake of ${ }^{14} \mathrm{C}$-glycine into the nucleic acid and protein fractions determined.

Fig. 2. Inhibition of nucleic acid synthesis. Saccharomyces carlsbergensis (equiv. $1 \mathrm{mg}$. dry weight $/ \mathrm{ml}$.) was incubated aerobically at $25^{\circ}$ in defined medium containing ${ }^{14} \mathrm{C}$ glycine and actidione as required. Organisms were harvested after $2 \mathrm{hr}$., fractionated by the method of Schmidt \& Thannhauser and the uptake of ${ }^{14} \mathrm{C}$-glycine into the RNA and DNA fractions determined.

fraction, but after $\mathbf{3 0}$ min. the rate of incorporation was lower than that into the control organisms. At concentrations of actidione greater than $1 \cdot 0 \mu \mathrm{g} . / \mathrm{ml}$. the initial rate of uptake was decreased and after $60 \mathrm{~min}$. incorporation had almost completely stopped. The results presented so far lead to the conclusion that concentrations of actidione equal to or greater than the minimum growth inhibitory concentration completely inhibit DNA synthesis, whereas the synthesis of RNA continues at the same or at a decreased rate for about $60 \mathrm{~min}$. before it too ceases.

Protein synthesis. Under the experimental conditions used, addition of ${ }^{14} \mathrm{C}$-labelled glycine to a suspension of Saccharomyces carlsbergensis resulted in the irreversible incorporation of ${ }^{14} \mathrm{C}$ in the glycine and serine of the protein fraction; this incorporation was used as a method of following protein synthesis. Actidione at the minimum growth inhibitory concentration almost completely inhibited the incorporation of glycine into the protein fraction (Fig. 1). The adaptive formation of the maltozymase system in $S$. carlsbergensis was similarly inhibited by actidione (Table 1). The effect of less than growth-inhibitory concentrations of actidione on the rate of incorporation 
Table 1. Effect of actidione on the synthesis of the adaptive maltozymase system by Saccharomyces carlsbergensis

Adaptation system; McIlvaine buffer (pH 5.0), $\left(\mathrm{NH}_{4}\right)_{2} \mathrm{HPO}_{4} 0.1 \%(\mathrm{w} / \mathrm{v}),\left(\mathrm{NH}_{4}\right) \mathrm{H}_{2} \mathrm{PO}_{4}$ $0 \cdot 1 \%(\mathrm{w} / \mathrm{v})$, actidione as required and organisms added to a final density equiv. $1 \cdot 0 \mathrm{mg}$. dry weight $/ \mathrm{ml}$. Organisms were harvested after $2 \mathrm{hr}$. aerobic incubation at $25^{\circ}$, washed twice with distilled water and the maltozymase activity determined manometrically.

\begin{tabular}{|c|c|c|c|}
\hline \multirow{2}{*}{$\begin{array}{c}\text { Actidione } \\
\text { concentration } \\
(\mu \mathrm{g} . / \mathrm{ml} .)\end{array}$} & \multicolumn{2}{|c|}{$\begin{array}{l}Q_{\mathrm{cos}}^{\mathrm{No}} \text { (maltose) } \\
\text { at } 25^{\circ}\end{array}$} & \multirow{2}{*}{$\begin{array}{c}\text { Inhibition } \\
(\%)\end{array}$} \\
\hline & Initial & Final & \\
\hline Nil & $11 \cdot 2$ & 280 & - \\
\hline $0 \cdot 1$ & $11 \cdot 2$ & 151 & 48 \\
\hline $1 \cdot 0$ & $11 \cdot 2$ & 15 & 98.5 \\
\hline 10 & $11 \cdot 2$ & 12 & $99 \cdot 7$ \\
\hline
\end{tabular}

of ${ }^{14} \mathrm{C}$-labelled glycine was examined with washed suspensions and with logarithmically growing cultures; the results were similar in both cases (Fig. 4). The inhibition of protein synthesis differed from that of RNA synthesis in that concentrations of actidione greater than $1.0 \mu \mathrm{g} . / \mathrm{ml}$. almost completely inhibited protein synthesis and at lower concentrations the time lag before inhibition occurred was less than in the case of nucleic acid.

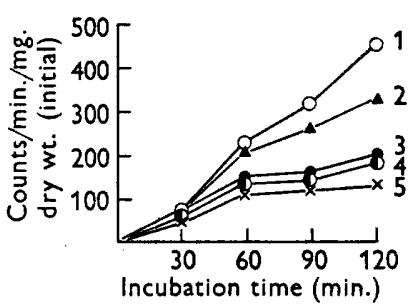

Fig. 3

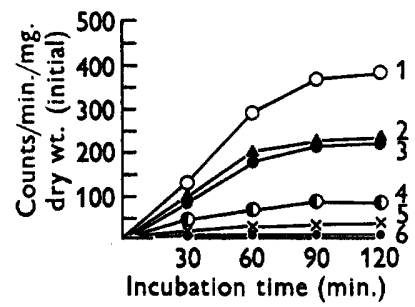

Fig. 4

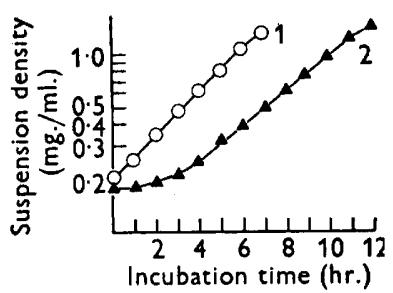

Eig. 5

Fig. 3. Inhibition by actidione of the incorporation of ${ }^{14} \mathrm{C}$-glycine into the nucleic acid fraction of washed suspensions of Saccharomyces carlsbergensis. S. carlsbergensis (equiv. $0.6 \mathrm{mg}$. dry weight $/ \mathrm{ml}$.) was incubated aerobically in defined medium containing ${ }^{14} \mathrm{C}$ glycine $(0.1 \mu \mathrm{mole} / \mathrm{ml}$., $0.1 \mu \mathrm{c} / \mathrm{mole})$ and actidione as required. Organisms were harvested after various time intervals and the uptake of ${ }^{14} \mathrm{C}$-glycine into the nucleic acid fraction determined. Actidione concentration $(\mu \mathrm{g} . / \mathrm{ml}$. ) : curve 1 , control ; curve 2, 0.05 ; curve $3,0.5$; curve $4,1.0$; curve $5,10.0$.

Fig. 4. Inhibition by actidione of the incorporation of ${ }^{14} \mathrm{C}$-glycine into the protein fraction of washed suspensions of Saccharomyces carlsbergensis. S. carlsbergensis (equiv. $0 \cdot 6 \mathrm{mg}$. dry weight $/ \mathrm{ml}$.) was incubated aerobically at $25^{\circ}$ in defined medium containing ${ }^{14} \mathrm{C}$ glycine (0.1 $\mu \mathrm{mole} / \mathrm{ml}$., $0 \cdot 1 \mu \mathrm{c} / \mu \mathrm{mole})$ and actidione as required. Organisms were harvested after various time intervals and the uptake of glycine into the protein fraction determined. Actidione concentration $(\mu \mathrm{g} . / \mathrm{ml}$.): curve 1 , control; curve $2,0.05$; curve 3, 0.1 ; curve $4,0.5$; curve $5,1.0$; curve $6,10.0$.

Fig. 5. Growth of Saccharomyces carlsbergensis after preincubation with actidione. S. carlsbergensis (equiv. $1.0 \mathrm{mg}$. dry weight $/ \mathrm{ml}$.) was incubated aerobically at $25^{\circ}$ in defined medium with or without actidione $(1 \cdot 0 \mu \mathrm{g} . / \mathrm{ml}$.). Organisms were harvested after $2 \mathrm{hr}$., washed twice with distilled water, resuspended in defined medium and incubated aerobically at $25^{\circ}$. Growth was followed by estimating the optical density of the suspension at $420 \mathrm{~m} \mu$. $\bigcirc-\mathrm{O}$, control culture; $\Delta-\Delta$, preincubated culture. 


\section{Effect of preincubating with actidione on the subsequent synthesis of nucleic acid and protein}

Actidione has been shown to be fungistatic, and since it is possible to reverse the inhibition by washing out the antibiotic, the synthesis of nucleic acid and protein after removal of the antibiotic was studied. Organisms which had been first incubated with or without actidione were washed and then re-incubated in fresh medium with ${ }^{14} \mathrm{C}$-labelled glycine; growth and the incorporation of isotope into the nucleic acid and protein fractions were determined at hourly intervals (Fig. 5). The ratios of the specific activities of the nucleic acid and protein fractions were approximately constant during the period of recovery and subsequent logarithmic growth (control nucleic acid/protein $=\mathbf{0 . 7 3 6}$ standard deviation $=0.06$; preincubated with actidione nucleic acid/protein $=$ 0.740 standard deviation $=0 \cdot 13$ ). It is therefore unlikely that preferential synthesis of either nucleic acid or protein occurs following release from actidione inhibition.

The effect of other antifungal agents on nucleic acid and protein synthesis in Saccharomyces carlsbergensis

Actidione at concentrations greater than $1.0 \mu \mathrm{g} . / \mathrm{ml}$. prevents synthesis of DNA and protein and causes inhibition of RNA synthesis after a short time lag. The results suggest that the synthesis of protein is not necessary for the concomitant synthesis of RNA, but throw no light on the inter-relations of DNA and protein synthesis except that the reaction(s) inhibited by actidione is (are) involved in the synthesis of both DNA and protein. Some other growth inhibitors were investigated in an attempt to elucidate further the interrelations of nucleic acid and protein synthesis in Saccharomyces carlsbergensis.

The compounds used were: Crag 341 (2-heptadecyl-2-imidazoline); frequentin, an antibiotic produced by some strains of Penicillium frequentans Westling and shown by Curtis, Hemming \& Smith (1951) to prevent spore germination in certain fungi and also to possess a high degree of surface activity; gliotoxin (Weindling \& Emerson, 1936; Dutcher, Johnson \& Bruce, 1945); viridin, produced by Trichoderma viride and shown by Brian \& McGowan (1945) to in hibit the germination of Botrytis allii conidia at 0.005 $\mu \mathrm{g} . /$ ml.; ethidium bromide. Frequentin, gliotoxin and viridin inhibited nucleic acid and protein synthesis by Saccharomyces carlsbergensis to similar extents and inhibition was complete at concentrations equal to or greater than the growth inhibitory concentration (frequentin, $30 \mu \mathrm{g} . / \mathrm{ml}$.; gliotoxin, $30 \mu \mathrm{g} . / \mathrm{ml}$.; viridin, $0 \cdot 1 \mu \mathrm{g} . / \mathrm{ml}$.).

Crag 341. Inhibition of growth of Sclerotinia fructicola by Crag 341 is annulled by guanine (West \& Wolf, 1955) and it was therefore of interest as a possible specific inhibitor of nucleic acid synthesis. Figure 6 shows the effect of Crag 341 on nucleic acid and protein synthesis; the addition of purines decreased the degree of inhibition. Aeration of the tubes containing the higher concentrations of Crag 341 caused excessive foaming and subsequent studies demonstrated that the compound was acting as a detergent. Table 2 shows the 
effect of Crag 341 on the release of soluble compounds from a suspension of Saccharomyces carlsbergensis.

Ethidium bromide. Ethidium bromide is an effective inhibitor of certain protozoa and has been shown to interfere with nucleic acid and protein synthesis in Strigomonas oncopelti (Newton, 1957). In view of an apparent structural similarity to actidione its effect on nucleic acid and protein synthesis in yeast was investigated. At concentrations of ethidium bromide less than the minimum growth inhibitory concentration both RNA and DNA synthesis were more sensitive to inhibition than protein synthesis (Fig. 7).

\section{Table 2. The release of soluble ultraviolet-absorbing material from}

Saccharomyces carlsbergensis on incubation with Crag 341

Washed organisms (equiv. 1.0 mg. dry weight $/ \mathrm{ml}$.) were incubated with Crag 341. Samples were taken at intervals, organisms removed by centrifugation and the optical density at $260 \mathrm{~m} \mu$ determined in the Beckman Model DU spectrophotometer.

Inhibitor concn. ( $\mu \mathrm{g} . / \mathrm{ml}$.) Incubation time (min.)
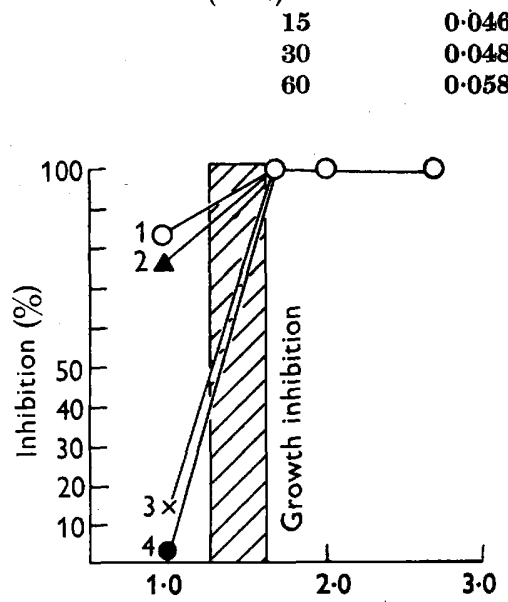

Log concentration Crag $341(\mu \mathrm{g} . / \mathrm{ml}$.)

Fig. 6 $\log I_{0} / I$ at $260 \mathrm{~m} \mu$ of the suspending medium

$\overbrace{0.0}^{0.3} \quad 10.0 \quad 30.0 \quad 100 \quad 1000$

$\begin{array}{llllll}0.046 & 0.054 & 0.104 & 0.215 & 0.305 & 0.375 \\ 0.048 & 0.053 & 0.098 & 0.210 & 0.288 & 0.380 \\ 0.058 & 0.062 & 0.096 & 0.223 & 0.292 & 0.400\end{array}$

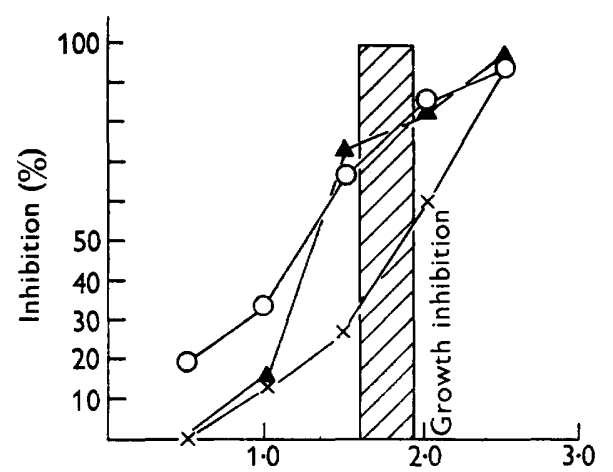

Log concentration ethidium bromide $(\mu \mathrm{g} . / \mathrm{ml}$.)

Fig. 7

Fig. 6. Inhibition of protein and nucleic acid synthesis by the fungicide Crag 341. Saccharomyces carlsbergensis (equiv. $1.0 \mathrm{mg}$. dry weight $/ \mathrm{ml}$.) was incubated aerobically at $25^{\circ}$ in defined growth medium containing ${ }^{14} \mathrm{C}$-glycine $(0.1 \mu \mathrm{mole} / \mathrm{ml} ., 0 \cdot 1 \mu \mathrm{c} / \mu \mathrm{mole})$ and Crag 341 as required. Organisms were harvested after $2 \mathrm{hr}$., fractionated into the nucleic acid (curves 1 and 4) and protein (curves 2 and 3 ) fractions determined. Guanine was added to the growth medium in 3 and 4.

Fig. 7. Inhibition of nucleic acid and protein synthesis by ethidium bromide. Saccharomyces carlsbergensis (equiv, 1.0 mg. dry weight/ml.) was incubated aerobically at $25^{\circ}$ in defined medium to which ethidium bromide had been added as required. Organisms were harvested after $2 \mathrm{hr}$., fractionated by the method of Ogur \& Rosen (1950) and the synthesis of nucleic acid and protein determined. $O-O$, RNA; $\triangle-\Lambda, D N A$; $x \rightarrow x$, protein. 


\section{DISCUSSION}

The action of actidione resembles that of the antimicrobial antibiotics chloramphenicol, aureomycin and terramycin in that the primary point of inhibition appears to lie in the sequence of reactions leading to the synthesis of nucleic acid and protein. Actidione differs from these antibiotics in that not only does it inhibit the synthesis of protein at the minimum growth inhibitory concentration but there is also a differential effect on the synthesis of the two types of nucleic acid. At the minimum growth inhibitory concentration the synthesis of DNA and protein is completely blocked, whereas the synthesis of RNA continues at a slower rate for some time after the addition of actidione to the yeast suspension. Actidione has a similar effect on nucleic acid and protein synthesis in Aspergillus nidulans (Shepherd, 1958). It has not been possible to locate the exact point of inhibition in the sequence of reactions leading to the synthesis of DNA and protein. Attempts have been made to separate the steps leading to the synthesis of nucleic acid and protein and to study the effect of actidione on individual reactions; but so far no positive results have been obtained.

The author wishes to express his thanks to the Medical Research Council for a Scholarship for Training in Research Methods, to Gonville and Caius College, Cambridge, for a Shuttleworth Research Studentship, and to Dr R. Davies for much helpful advice and encouragement. He is also indebted to Dr P. W. Brian, F.R.S., for gifts of the antibiotics viridin, gliotoxin and frequentin and to $\mathrm{Dr} B$. A. Newton for a gift of ethidium bromide.

\section{REFERENCES}

Brian, P. W. \& McGowan, J. R. (1945). Viridin: a highly fungistatic substance produced by Trichoderma viride. Nature, Lond. 156, 144.

Burton, K. (1956). A study of the conditions and mechanism of the diphenylamine reaction for the colorimetric estimation of deoxyribonucleic acid. Biochem. $J$. $62,315$.

Chibnali, A. C., Rees, M. W. \& Williams, E. F. (1943). The total nitrogen content of egg albumin and other proteins. Biochem. J. 37, 354.

Creaser, E. H. (1955). The induced (adaptive) synthesis of $\beta$-galactosidase in Staphylococcus aureus. J. gen. Microbiol. 12, 288.

Curtis, P. J., Hemming, H. G. \& Smith, W. K. (1951). Frequentin; an antibiotic produced by some strains of Penicillium frequentans Westling. Nature, Lond. $167,557$.

Davies, A. (1956). Invertase formation in Saccharomyces fragilis. J. gen. Microbiol. $14,109$.

Davies, R., Falkiner, E. A., Wilkinson, J. F. \& Peel, J. L. (1951). Ester formation in yeasts. 1. Ethyl acetate formation by Hansenula species. Biochem. J. 49, 58 .

Demoss, J. A. \& Novelri, G. D. (1955). An amino acid dependent exchange between inorganic pyrophosphate and ATP in microbial extracts. Biochem. biophys. Acta, 18, 592.

Dutcher, J. D., Johnson, J. R. \& Bruce, W. F. (1945). Gliotoxin. vi. The nature of the sulphur linkages, conversion to desthiogliotoxin. J. Amer. chem. Soc. 67, 1736 . 
Fitzgerald, R. J., Bernheim, F. \& Fitzgerald, D. B. (1948). The inhibition by streptomycin of adaptive enzyme formation in Mycobacteria. J. biol. Chem. 175, 195.

Gale, E. F. \& Folkes, J. P. (1953). The assimilation of amino acids by bacteria. 14. Nucleic acid and protein synthesis in Staphylococcus aureus. Biochem. J. 53, 483.

Gale, E. F. \& Paine, T. F. (1951). The assimilation of amino acids by bacteria. 12. The action of inhibitors and antibiotics on the accumulation of free glutamic acid and the formation of combined glutamate in Staphylococcus aureus. Biochem. J. 48, 298.

Gros, F. \& Gros, F. (1956). Rôle des aminoacides dans la synthèse des acides nucléiques chez Escherichia coli. Biochem. biophys. Acta, 22, 200.

Hahn, F. E. \& Wrsseman, C. L. (1951). Inhibition of adaptive enzyme formation by antimicrobial agents. Proc. Soc. exp. Biol., N.Y. 76, 533.

Hall, E. A., Kavanagh, F. \& Asheshov, I. N. (1951). Action of forty-five antibacterial substances on bacterial viruses. Antibiot. \& Chemother. 1, 369.

Hughes, D. E. (1951). A press for disrupting bacteria and other micro-organisms. Brit. J. exp. Path. 32, 97.

JoHnson, M. J. (1941). Isolation and properties of a pure yeast polypeptidase. J. biol. Chem. 137, 575.

KERRIDGE, D. (1957). The effect of actidione on protein and nucleic acid synthesis in Saccharomyces mandshuricus. J. gen. Microbiol. 16, v.

Loveless, L. E., Spoerl, E. \& Weisman, T. H. (1954). A survey of the effects of chemicals on division and growth of yeast and Escherichia coli. J. Bact. 68, 637 .

McIlvaine, T. C. (1921). A buffer solution for colorimetric comparison. J. biol. Chem. 49, 183.

MarKHAM, R. (1942). A steam distillation apparatus suitable for micro-Kjeldahl analysis. Biochem. J. 35, 790.

Newton, B. A. (1957). The mode of action of the phenanthridines: the effect of ethidium bromide on cell division and nucleic acid synthesis. J. gen. Microbiol. $17,718$.

OGur, M. \& Rosen, G. (1950). The nucleic acids of plant tissues. 1. The extraction and estimation of ribonucleic acid and deoxyribonucleic acid. Arch. Biochem. Biophys. 25, 262.

Schmidt, G. \& Thannhauser, S. J. (1945). A method for the determination of deoxyribonucleic acid, ribonucleic acid and phosphoproteins in animal tissues. J. biol. Chem. 161, 83.

SHEPHERD, C. J. (1958). Inhibition of protein and nucleic acid synthesis in Aspergillus nidulans. J. gen. Microbiol. 18, iv.

Szilvinyi, A., Kuaus-Hofer, H. \& Rauch, C. (1954). Zur Verwendung des Actidions in der biologischen Betriebskontrolle. Mitt. VersAnst. Gärungsgew. 8, 101.

Umbreit, W. W., Burris, R. H. \& Stauffer, J. F. (1949). Manometric techniques and Tissue Metabolism. Minneapolis: Burgess Publishing Co.

Weinding, R. \& Emerson, O. H. (1936). The isolation of a toxic substance from the culture filtrate of Trichoderma. Phytopathology, 26, 1068.

WeST, B. \& WoLF, F. T. (1955). The mechanism of action of the fungicide 2-heptadecyl-2-imidazoline. J. gen. Microbiol. 12, 396.

WhIFFen, A. J. (1948). The production, assay and antibiotic activity of actidione, an antibiotic from Streptomyces griseus. J. Bact. 56, 283.

Whiffen, A. J., Bohonas, N. \& Emerson, R. L. (1946). The production of an antifungal antibiotic by Streptomyces griseus. J. Bact. 52, 610.

Wisseman, C. L., Hahn, F. E., Hopps, H. \& Smadel, J. E. (1953). Chloramphenicol inhibition of protein synthesis. Fed. Proc. 12, 466. 